\title{
A PISA-based Student Worksheet for Better Understanding of Mathematical Concept
}

\author{
Sutama $^{1}$, Harun Joko Prayitno ${ }^{2}$, Sofyan Anif ${ }^{3}$, Nuqthy Faiziyah ${ }^{4}$, Meggy Novitasari $^{5}$, \\ Muhammad Wildan Fadhilah ${ }^{6}$ \\ sutama@ums.ac.id ${ }^{1}$, harun.prayitno ${ }^{2}$, sofyan.anif@ums.ac.id ${ }^{3}$, nuqthy.faiziyah@ums.ac.id ${ }^{4}$, \\ a410130043@student.ums.ac.id ${ }^{5}$, a410150171@student.ums.ac.id ${ }^{6}$ \\ Universitas Muhammadiyah Surakarta ${ }^{1,2,3,4,5,6}$ \\ Surakarta, Indonesia
}

\begin{abstract}
A student worksheet is one of the teaching materials to improve student understanding in the classroom. However, many teachers could not effectively arrange and utilize it so that the learning objectives stated might not be reached. This study aims to generate a PISA-based student worksheet on valid and practical content and expose the effect on the ability to understand students' mathematical concepts. Using development research of a preliminary research, development phase, and assessment, the worksheet is composed. Besides, a test is used to determine the effectiveness of worksheets and another test is also to find out the effect of worksheets that have been made on the ability to understand mathematical concepts. As a result, this study has produced a valid and practical PISA-based student worksheet. The thing that is distinctive of this worksheet is that the question contains Sharing Task and Jumping Task. The result also shows that the worksheet could improve student understanding of a mathematical concept.
\end{abstract}

Keywords: mathematical concept, PISA, student worksheet, sharing task, jumping task.

\section{Introduction}

Understanding concepts is one of the mathematical skills or skills that is expected to be achieved in learning mathematics that is by showing understanding mathematical concepts learned, explaining the interrelationships between concepts and apply concepts or algorithms in a flexible, accurate, efficient and precise manner solution to a problem. Mathematical understanding will be meaningful if learning mathematics is directed at developing the ability of inter mathematical connections ideas, understanding how mathematical ideas are related to one another so that a comprehensive understanding is built up, and deep mathematics is used context outside of mathematics.

The use of student worksheets is expected to be able to change the conditions of learning from what the teacher usually has to determine "what is learned" to "how to provide and enrich student learning experiences". Student learning experiences can be obtained through a series of activities to explore the environment through active interaction with friends, the environment, and other resource persons. Presentation of mathematics learning by using worksheet demands active participation from students because student worksheets is a form of teacher's effort to guide students in a structured manner, through activities that can provide an attraction to students to study mathematics. Through learning with the worksheet, the effectiveness of the 
teaching and learning process can be improved. Although many forms of worksheets are found in the field, teachers do not know how good student worksheets criteria can be used to help achieve learning objectives.

\section{Literature Review}

In the process of learning mathematics, understanding concepts is a very important part. Understanding mathematical concepts is an important foundation for thinking in solving mathematical problems and everyday problems.

Mathematical thinking means (1) developing a mathematical view, assessing the process of mathematical and abstraction, and have the pleasure to apply it, (2) develop competence, and use it in mathematical understanding. The implication is how the teacher should design learning well, learning with characteristics that how to be able to help students build meaningful understanding [1]

Understanding of mathematical concept is a student competence to[2]:

- Explaining a concept could also be interpreted as an ability of a student to restate what they had already received to other people, for instance when they study about a circle, the definition, and the elements, they could restate them. Answering questions such as "what is a circle?" and "how a plan figure is can be considered as a circle" is tranquil.

- Applying a concept in various situations. for example, in daily life, if a student intends to give his friend a birthday gift in the form of a tin piggy bank that has been coated with a cloth, the can is available at home but the fabric must be purchased. The student must think about how many meters of fabric he should buy? How much money do you have to have to buy fabric? To think about how much fabric to buy means that the student already knows the concept of the surface area of the can to be covered and the concept of social arithmetic

- Developing some consequences of a concept, it can be interpreted that students understand a concept as a result student can solve every problem correctly.

A student worksheet is one of the teaching materials to enhance student understanding of a certain concept. The student worksheet consists of tasks to be done by the student and usually in the form of instructions, steps to complete the task. The task is proposed in the activity sheets should represent the competencies to be achieved[3]. A student worksheet is a teaching material that students could learn independently. It should at least contain the title, basic competencies, time allocation, task requirements, sufficient information, working stapes, and expected report[4]. The essential issue is that worksheet contains stages should be accomplished by the student to obtain a concept [5]

Advantages of utilizing student worksheet in learning are 1) enhancing student activity, 2) facilitating student to develop certain concept, 3) leading student to discover and develop process skill, 4) as a guide for teacher and student in learning, 5) helping student acquire annotation and further information about the topic studied[6]. Steps to arrange student worksheets are 1) curriculum analyzing 2) stating the title, 3) composing the worksheet[7].

The development of comparative assessments on an international scale such as PISA which aims to ensure the capacity of individuals to apply mathematics to life-like problems is a reflection of the government's attention to the mathematical abilities of their citizens [8]. Program for International Student Assessment or PISA committed by OECD (Organization for Economic Cooperation and Development), is an international program to monitor the outcomes of the 
education system, in terms of student achievement[9]. The main concept of PISA is literacy includes reading literacy, mathematics literacy, and science literacy. The principal objective of the PISA surveys is to notify the decision making of educational researchers and policymakers such that their decisions have a larger impact at the real classroom level[10]. PISA has been influential in creating a sense of worldwide educational accountability, leading to improved internal attention upon national accountability mechanisms[11].

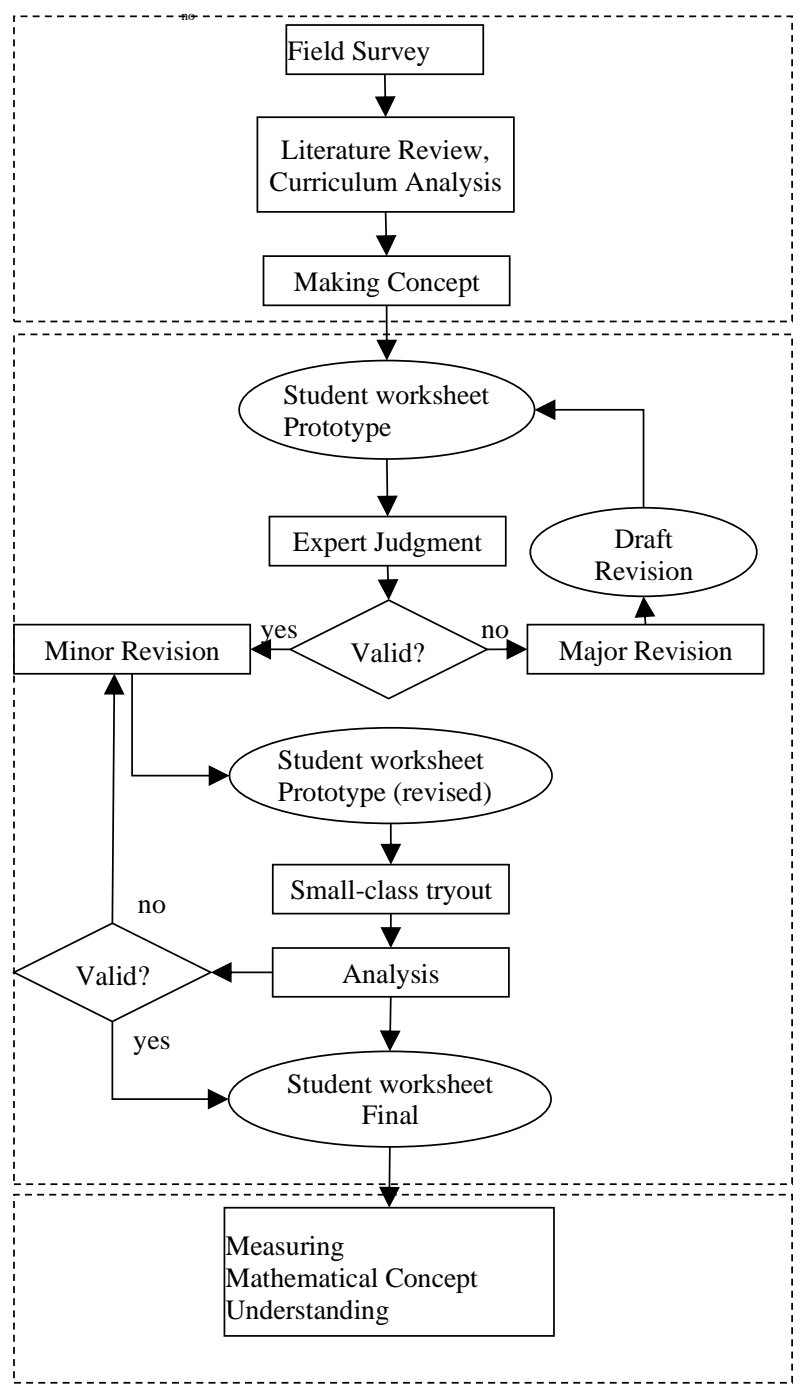

Fig. 1. Research and Development Procedure

Understanding of mathematics is essential to a young individual's prepares for life in current society. A growing percentage of problems as well as situations encountered in daily activities, involving professional contexts, need certain level of mathematics understanding, mathematical 
reasoning, and mathematical tools, before they could completely understood and addressed. Thus, mathematical literacy is critical for young people to confront issues and challenges in the personal, occupational, societal, and scientific aspects of their lives.

Mathematical PISA question has several components. Those are [12]:

1. Mathematical content that is directed for assessment items that are quantity; change and relationships; space and shape; uncertainty and data.

2. The context in which the assessment items are set, namely personal, occupational, societal, and scientific.

3. The mathematical process describing what individuals do to connect problems to certain mathematics concepts and to solve the problem as well as depicting the capabilities that underlie those processes, that is a reproduction, connection, reflection.

\section{Research Method}

This is design research with the type of research development or development studies. Research and development mean a process to develop a product that has already be existent [13]. This kind of research in education aims to design or develop an intervention such as program, learning resources, learning strategies, product, and also system as a solution for problems in education and to increase knowledge or develop the character of intervention in education. The model of this research consists of a preliminary research phase, development or prototyping phase, and assessment phase[14]. The model then decomposes into several steps as shown in the Fig. 1 Research and Development Procedure.

\section{Result and Discussion}

A preliminary study performed by interviewing students and teachers could be noticed that student worksheet used in the classroom was taken from some publishers whereas the content as well the body content arrangement might not suitable for students with their particular character of learning. Likewise, teaching material should display a complete figure of competencies that students will master in learning activities[4]. Moreover, the worksheet should contain stages should be accomplished by the student to obtain a concept[5] 
The field survey also expresses the worksheet was not satisfying characteristic of a good student worksheet as stated in the literature review. Generally, it does not inform steps to accomplish tasks assigned. Question stimulation does not reflect the daily problem or situation so it might not improve mathematical thinking. Furthermore, students' understanding of the mathematical concept would not be enhanced.

\subsection{PISA-based Student Worksheet Design}

Literature review and curriculum analysis being held afterward to obtain the concept of the student worksheet. Concept designing is Selecting a topic, as curriculum analysis result, "bangun ruang sisi lengkung" or space geometry was being selected to develop the worksheet. It is a part of mathematical topics in junior high school grade IX.

Afterward, arranging the material, the material presented and an example of the problem of the material based on situations encountered daily. The most important part of a worksheet that is how the questions are presented starting from the exercise to the measurement. The thing that is distinctive of this worksheet is that the question contains Sharing Task and Jumping Task as described below.

\section{1) Sharing Task}

Sharing tasks contain problems that have the same difficulty level as the questions in the textbook. This task is intended to provide a foundation for students to be ready to meet more challenging tasks. Sharing tasks is more often done individually, but the broad learning space of each other lies.

Sharing Task is given a few moments after a teacher doing a review or brainstorming at the beginning of the learning process. Every student has a certain time that has been set by the teacher to collaborate with the other within their groups discussing the contents of the task. In this case, students have the opportunity to interact. Students who have below-average comprehension skills and who feel they have not understood the material will have difficulty in understanding and completing the given assignment. Meanwhile, students who have above average abilities or those intelligent students will easily complete the given task. This is where the learning process creates a state of mutual benefit for both types of students

The advantage of such a task is that smart students will help students who have not been able to complete the task. Sometimes students will understand more easily when explained by their peers. Students whom help and students assisted, both benefits. Students who help get roles like a teacher. This will strengthen their understanding of the particular topic they discussed in the discussion. They can also recall basic materials when working on assignments to help their friends understand the assignments.

\section{2) Jumping Task}

Knowledge is spread among people and the environment, which includes objects, tools, artifacts, books, and communities where people are located. This shows that acquiring knowledge can be achieved well through interaction with others in joint activities. Knowledge is also constructed collaboratively between individuals and the situation can be adjusted by each individual. One that can be used is a collaborative learning model[15]. 
Jumping tasks are tasks that must be completed collaboratively (not cooperatively) with group settings. Jumping tasks contain questions or problems that force students to think more. This type of task is given with an intention that students can think more critically and challenged so that students will experience 'leap' of learning to drive them to think harder and to obtain something out of what is learned and usually cannot by themselves, need discussion partners. However, the questions in this assignment are still in the zone of proximal development (ZPD) students.

The zone of proximal development is the zone between the actual and potential development level. The actual development level is seen from the ability of children in completing tasks independently. Whereas, the level of potential for development is seen from the students' ability to accomplish the task or solve problems with the help of adults. The discussion of sharing tasks at the beginning of learning becomes a strong asset for students to complete their jumping tasks independently.

\subsection{Assessment of the design}

The PISA-oriented worksheet development was validated by 2 material experts from lecturers and teachers and 1 media expert from instructional media lecturers. Based on the results of three validators, an average percentage of $83.7 \%$ was found to be valid which can be seen in Tabel 1 below.

Table 1. Validation Result

\begin{tabular}{lll}
\hline Examined Aspects & Percentage & Criteria \\
\hline Learning Material Expert & & \\
Content & 79.8 & valid \\
Construct & 85 & strongly valid \\
Language & 82.3 & valid \\
Learning Media Expert & & \\
Graphic Design & 87.6 & strongly valid \\
Language & 84.5 & strongly valid \\
Average & 83.7 & Valid \\
\hline
\end{tabular}

The content aspect in the PISA-oriented worksheet consists of nine indicators that are categorized as valid. This is because the concept of the material in the worksheet is following the 2013 curriculum, which activates students in learning because PISA-generated questions use context in daily life so that students feel close to the problem. Furthermore, it will make you more motivated to learn. Along with increasing student motivation is expected to improve learning outcomes. This is consistent with Widjaja's research (2013) that the habit of using the PISA model questions in learning, the use of context is also considered very important. This is done so that in learning students can be motivated in learning mathematics[16].

In addition, The Cornerstone of Tech Prep (1999) states learning to use context makes students find meaningful relationships between abstract ideas and practical applications in realworld contexts[17]. UNESCO (2008) also state that the use of local contexts can help students understand mathematical phenomena from the perspective of their own life experiences. This makes mathematics much more interesting and useful for all students[18]. A research conducted by Kadir, K., \& Masi, L. (2013) claims contextual questions that are more related to the daily 
lives of students in their homes are very interesting to enable students in learning. Those kinds of questions will also challenge students' mathematical thinking processes[19].

The validation of media experts consisted of 2 aspects of evaluation, namely graphic design aspects and worksheet layout. In the graphic design aspect, which consists of seven statements namely regarding the appropriateness of the use of letters, the attractiveness of colors, and the accuracy of the location of the images contained in the worksheet is considered to be very valid. This is because the use of letters used in worksheets is clear and easy to read. And the use of color and color selection in student worksheets has the attraction of students' interest by having different colors on each title of the activity. With a different color in each activity can direct the focus and attention of students in every 8 learning activities so that PISA-oriented worksheet is feasible to use. As expressed by Sadiman (2012) that with the use of interesting learning media in the learning process can arouse interest in learning so that learning goals are achieved[20].

Furthermore, the innovative aspect of presenting material or layout consisting of five statements about the presentation of images, and the design of the worksheet has been considered to be very valid. This is because the appearance of the worksheet has a strong and resistant printing. At the presentation of the image has a clear image display and has a regular worksheet page design. So that it can make it easier for students to see each page of the worksheet. With the ease of use of the worksheet can also make it easier for students to understand every step of the activities contained in the worksheet. As said by Prastowo (2015) that the simplicity of the design and the attractiveness of the layout of the images on teaching materials can attract the attention of students[7].

The effectiveness analysis was carried out using a mathematical concept understanding test. Student test results are assessed according to the scoring guidelines. The maximum score for this test is 100. The learning device developed is said to be effective if more than $70 \%$ of students have a minimum understanding of concepts in the high category based on test results. Guidelines in determining the category of students' concept understanding abilities can be seen in the following Table 2 below.

The test results show that out of 34 students, only 6 have medium and low scores, as well as no student, has a poor understanding of mathematical concepts. As a result, as many as $82.3 \%$ have a high category and very high. That is, students 'worksheet was arranged could be categorized as effective teaching materials.

Table 2. Categories of Students' Concept Undestanding

\begin{tabular}{ll}
\hline Score Range & Category \\
\hline $85<\mathrm{N} \leq 100$ & very good \\
$75<\mathrm{N} \leq 84$ & good \\
$56<\mathrm{N} \leq 84$ & medium \\
$41<\mathrm{N} \leq 55$ & low \\
$0<\mathrm{N} \leq 40$ & poor \\
$85<\mathrm{N} \leq 100$ & very good
\end{tabular}

\subsection{Measuring Mathematical Concept Understanding}

An experimental study was carried out as a measure of the ability to understand mathematical concepts using PISA-based worksheets. Two classes were taken from a junior high school in Karanganyar Regency, one as an experimental class where learning using a PISA-based 
worksheet was used, while the other class was used as a control class. Before being treated, a balance test is first performed to ensure the two classes are balanced. The balance test is carried out using the Z-test which is preceded by a normality test with the Kolmogorov-Smirnov Test.

The normality test is carried out by the Kolmogorov-Smirnov test for each experimental class and the control class. The results of the normality test can be seen in the following Table 3. It noticed that all calculations were performed with the IBM SPSS Statistics 21 assistance program.

Table 3. Normality Test

\begin{tabular}{llll}
\hline Class & \multicolumn{3}{l}{ Kolmogorov-Smirnov } \\
& Statistic & df & Sig. \\
\hline Experiment & .145 & 35 & .061 \\
Control & .120 & 34 & $.200 *$
\end{tabular}

It is an Obtained sig. for the experimental class and the control class respectively 0.061 and 0.200 , using a significance level of $5 \%$ it can be concluded that the two data are normally distributed. In other words, the data from each class is normally distributed.

The instrument used to measure students' understanding of mathematical concepts is a test instrument. The instrument consists of 5 questions that meet the indicators of understanding mathematical concepts. The validity of the instrument was carried out to 2 experts to see the suitability of the questions with the indicators, problem construction, and language used. Both validators stated that the test instrument was valid with minor revision.

Table 4. Data Description of Students` Mathematical Concept Understanding Ability

\begin{tabular}{llll}
\hline Class & \multicolumn{3}{l}{ Central Tendency Measure } \\
\hline & $\begin{array}{l}\text { Number of student } \\
(\mathrm{N})\end{array}$ & Mean & $\begin{array}{l}\text { Deviation } \\
\text { standard }\end{array}$ \\
\hline Experiment & 35 & 82.71 & 8.86 \\
Control & 34 & 71.47 & 11.78
\end{tabular}

The average difference test is done by the independent $t$-test. The results are presented in the following Table 5.

Table 5. Independent Test

\begin{tabular}{llllll}
\hline Class & \multicolumn{2}{l}{ Central Tendency Measure } & & & \\
\hline & $\begin{array}{l}\text { Levene's Test for Equality } \\
\text { of Variances }\end{array}$ & \multicolumn{2}{c}{ t-test for Equality of Means } \\
\hline & $\mathrm{F}$ & Sig. & $\mathrm{t}$ & $\mathrm{df}$ & Sig.(2-tailed) \\
\hline Experiment & 4.136 & .046 & 4.437 & 68 & .000 \\
Control & & & 4.437 & 63.357 & .000
\end{tabular}

The table above is the main table of the independent sample t-test analysis. It is recognized that 2 -way significance value ( $\mathrm{t}$-tailed) are $0,000<0.05$. Thus, there is a significant difference in score points between the control and treatment groups.

The results of the study are in line with research conducted by Park et.al (2016) which states that the way students express their understanding of volume is correlated to how they are 
structuring it[21]. J. C. Andamon and D. A. Tan (2018) also researched understanding mathematical concepts in secondary school, it stated that conceptual mathematics understanding is a knowledge that involves a thorough understanding of underlying and foundation concepts behind the algorithms performed in mathematics [22]

\section{Conclusion}

This research has produced a valid and effective PISA-based worksheet. The teaching material has been validated 3 experts' validator and has been tried to one of the classes to see its effectiveness. On the results of experimental studies using the PISA-based worksheet, it can be concluded that the PISA worksheet can improve students' understanding of mathematical concepts.

This research focuses on the development of a PISA-based student worksheet to improve students' understanding of mathematical concepts. Therefore, the suggestion for further research is another PISA-based teaching material that can improve other mathematical skills.

Acknowledgement. Thank you to Direktorat Riset dan Pengabdian Masyarakat Direktorat Jenderal Riset dan Pengembangan Kementerian Riset, Teknologi, dan Pendidikan Tinggi and Universitas Muhammadiyah Surakarta.

\section{References}

[1] A. . Schoenfeld, "Learning to Think Mathematically: Problem Solving, Metacognition and Sense of Mathematics.," in Handbook of Reasearch on Mathematics Teaching and Learning, New York: Macmillan, 1992, pp. 334-370.

[2] J. . Duffin and A. . Simpson, "A Search for understanding," J. Math. Behav., vol. 18, no. 4, pp. 415-427, 2000.

[3] Depdiknas, Kurikulum Tingkat Satuan Pendidikan. Jakarta: Direktorat Jendral Perguruan Tinggi, 2008.

[4] A. Prastowo, Panduan Kreatif Membat Bahan Ajar Inovatif, Menciptakan Metode Pembelajaran yang Menarik dan Menyenangkan. Yogyakarta: Diva Press, 2013.

[5] Trianto, Mendesain Model Pembelajaran Inovatif-Progresif. Jakarta: Kencana Prenada Group, 2011.

[6] Suyitno, Pemilihan Model-Model Pembelajaran dan Penerapannya di Sekolah. Jakarta: Pusdiklat, 2007.

[7] A. Prastowo, Panduan Kreatif Membuat Bahan Ajar Inovatif. Yogyakarta: Diva Press, 2015.

[8] V. Geiger, G. Stillman, J. Brown, P. Galbriath, and M. Niss, "Using mathematics to solve real world problems: the role of enablers," Math. Educ. Res. J., vol. 30, no. 1, pp. 7-19, 2018.

[9] OECD, PISA for Development Assessment and Analytical Framework. 2018.

[10] H. C. She, K. Stacey, and W. H. Schmidt, "Science and Mathematics Literacy: PISA for Better School Education," Int. J. Sci. Math. Educ., vol. 16, pp. 1-5, 2018. 
[11] J. Elliott, L. Stankov, J. Lee, and J. F. Beckmann, "What did PISA and TIMSS ever do for us?: the potential of large scale datasets for understanding and improving educational practice," Comp. Educ., vol. 55, no. 1, pp. 133-155, 2019.

[12] S. Ahyan, Z. Zulkardi, and D. Darmawijoyo, "Developing Mathematics Problems Based on Pisa Level of Change and Relationships Content," J. Math. Educ., vol. 5, no. 1, pp. 47-56, 2016.

[13] Sutama, Metode Penelitian Pendidikan (Kuantitatif, Kualitatif, PTK, R\&D). Surakarta: Fairuz Media, 2012.

[14] T. Plomp and N. Nieveen, Educational design research part A: an introduction. Enschede: SLO, 2007.

[15] L. S. Vygotsky, “Thinking and speech. In R. W. Rieber \& A. S. Carton (eds.)., The collected works of L. S. Vygotsky," in Problems of general psychology (pp., vol. 1, 1987, p. 1987.

[16] W. Widjaya, "The Used of Contextual Problems Support Mathematical Learning," J. Math. Educ., vol. 4, no. 2, pp. 151-159, 2013.

[17] The Cornerstone Tech Prep, Teaching Mathematics Contextually. Texas: CORD, 1999.

[18] UNESCO, Developing culturally contextualised mathematics resource materials: capturing local practices of Tamang and Gopali communities; a report; 2008. Kathmandu: Lusha Press, 2008.

[19] K. Kadir and L. Masi, "Penggunaan konteks dalam pembelajaran matematika untuk meningkatkan keterampilan sosial siswa SMP," Proceeding KNPM V Malang, pp. 786-796, 2013.

[20] Sadiman, Media Pendidikan. Depok: Rajawali Press, 2012.

[21] D. Y. Park, M. H. Park, and A. B. Bates, "Exploring Young Children's Understanding About the Concept of Volume Through Engineering Design in a STEM Activity: A Case Study," Int. J. Sci. Math. Educ., vol. 16, no. 2, pp. 275-294, 2018.

[22] J. C. Andamon and D. A. Tan, "Conceptual understanding, attitude and performance in mathematics of grade 7 students," Int. J. Sci. Technol. Res., vol. 7, no. 6, pp. 96$105,2018$.

[1] A. . Schoenfeld, "Learning to Think Mathematically: Problem Solving, Metacognition and Sense of Mathematics.," in Handbook of Reasearch on Mathematics Teaching and Learning, New York: Macmillan, 1992, pp. 334-370.

[2] J. . Duffin and A. . Simpson, "A Search for understanding," J. Math. Behav., vol. 18, no. 4, pp. 415-427, 2000.

[3] Depdiknas, Kurikulum Tingkat Satuan Pendidikan. Jakarta: Direktorat Jendral Perguruan Tinggi, 2008.

[4] A. Prastowo, Panduan Kreatif Membat Bahan Ajar Inovatif, Menciptakan Metode Pembelajaran yang Menarik dan Menyenangkan. Yogyakarta: Diva Press, 2013.

[5] Trianto, Mendesain Model Pembelajaran Inovatif-Progresif. Jakarta: Kencana Prenada Group, 2011.

[6] Suyitno, Pemilihan Model-Model Pembelajaran dan Penerapannya di Sekolah. Jakarta: Pusdiklat, 2007.

[7] A. Prastowo, Panduan Kreatif Membuat Bahan Ajar Inovatif. Yogyakarta: Diva Press, 2015.

[8] V. Geiger, G. Stillman, J. Brown, P. Galbriath, and M. Niss, "Using mathematics to solve real world problems: the role of enablers," Math. Educ. Res. J., vol. 30, no. 1, pp. 7-19, 2018. 
[9] OECD, PISA for Development Assessment and Analytical Framework. 2018.

[10] H. C. She, K. Stacey, and W. H. Schmidt, "Science and Mathematics Literacy: PISA for Better School Education," Int. J. Sci. Math. Educ., vol. 16, pp. 1-5, 2018.

[11] J. Elliott, L. Stankov, J. Lee, and J. F. Beckmann, "What did PISA and TIMSS ever do for us?: the potential of large scale datasets for understanding and improving educational practice," Comp. Educ., vol. 55, no. 1, pp. 133-155, 2019.

[12] S. Ahyan, Z. Zulkardi, and D. Darmawijoyo, "Developing Mathematics Problems Based on Pisa Level of Change and Relationships Content," J. Math. Educ., vol. 5, no. 1, pp. 47-56, 2016.

[13] Sutama, Metode Penelitian Pendidikan (Kuantitatif, Kualitatif, PTK, R\&D). Surakarta: Fairuz Media, 2012.

[14] T. Plomp and N. Nieveen, Educational design research part A: an introduction. Enschede: SLO, 2007.

[15] L. S. Vygotsky, "Thinking and speech. In R. W. Rieber \& A. S. Carton (eds.)., The collected works of L. S. Vygotsky," in Problems of general psychology (pp., vol. 1, 1987, p. 1987.

[16] W. Widjaya, "The Used of Contextual Problems Support Mathematical Learning," J. Math. Educ., vol. 4, no. 2, pp. 151-159, 2013.

[17] The Cornerstone Tech Prep, Teaching Mathematics Contextually. Texas: CORD, 1999.

[18] UNESCO, Developing culturally contextualised mathematics resource materials: capturing local practices of Tamang and Gopali communities; a report; 2008. Kathmandu: Lusha Press, 2008.

[19] K. Kadir and L. Masi, "Penggunaan konteks dalam pembelajaran matematika untuk meningkatkan keterampilan sosial siswa SMP,” Proceeding KNPM V Malang, pp. 786-796, 2013.

[20] Sadiman, Media Pendidikan. Depok: Rajawali Press, 2012.

[21] D. Y. Park, M. H. Park, and A. B. Bates, "Exploring Young Children's Understanding About the Concept of Volume Through Engineering Design in a STEM Activity: A Case Study," Int. J. Sci. Math. Educ., vol. 16, no. 2, pp. 275-294, 2018.

[22] J. C. Andamon and D. A. Tan, "Conceptual understanding, attitude and performance in mathematics of grade 7 students," Int. J. Sci. Technol. Res., vol. 7, no. 6, pp. 96$105,2018$.

[1] A. . Schoenfeld, "Learning to Think Mathematically: Problem Solving, Metacognition and Sense of Mathematics.," in Handbook of Reasearch on Mathematics Teaching and Learning, New York: Macmillan, 1992, pp. 334-370.

[2] J. . Duffin and A. . Simpson, "A Search for understanding," J. Math. Behav., vol. 18, no. 4, pp. 415-427, 2000.

[3] Depdiknas, Kurikulum Tingkat Satuan Pendidikan. Jakarta: Direktorat Jendral Perguruan Tinggi, 2008.

[4] A. Prastowo, Panduan Kreatif Membat Bahan Ajar Inovatif, Menciptakan Metode Pembelajaran yang Menarik dan Menyenangkan. Yogyakarta: Diva Press, 2013.

[5] Trianto, Mendesain Model Pembelajaran Inovatif-Progresif. Jakarta: Kencana Prenada Group, 2011.

[6] Suyitno, Pemilihan Model-Model Pembelajaran dan Penerapannya di Sekolah. Jakarta: Pusdiklat, 2007.

[7] A. Prastowo, Panduan Kreatif Membuat Bahan Ajar Inovatif. Yogyakarta: Diva Press, 
2015.

[8] V. Geiger, G. Stillman, J. Brown, P. Galbriath, and M. Niss, "Using mathematics to solve real world problems: the role of enablers," Math. Educ. Res. J., vol. 30, no. 1, pp. 7-19, 2018.

[9] OECD, PISA for Development Assessment and Analytical Framework. 2018.

[10] H. C. She, K. Stacey, and W. H. Schmidt, "Science and Mathematics Literacy: PISA for Better School Education," Int. J. Sci. Math. Educ., vol. 16, pp. 1-5, 2018.

[11] J. Elliott, L. Stankov, J. Lee, and J. F. Beckmann, "What did PISA and TIMSS ever do for us?: the potential of large scale datasets for understanding and improving educational practice," Comp. Educ., vol. 55, no. 1, pp. 133-155, 2019.

[12] S. Ahyan, Z. Zulkardi, and D. Darmawijoyo, "Developing Mathematics Problems Based on Pisa Level of Change and Relationships Content," J. Math. Educ., vol. 5, no. 1, pp. 47-56, 2016.

[13] Sutama, Metode Penelitian Pendidikan (Kuantitatif, Kualitatif, PTK, $R \& D$ ). Surakarta: Fairuz Media, 2012.

[14] T. Plomp and N. Nieveen, Educational design research part A: an introduction. Enschede: SLO, 2007.

[15] L. S. Vygotsky, "Thinking and speech. In R. W. Rieber \& A. S. Carton (eds.)., The collected works of L. S. Vygotsky," in Problems of general psychology (pp., vol. 1, 1987, p. 1987.

[16] W. Widjaya, "The Used of Contextual Problems Support Mathematical Learning," J. Math. Educ., vol. 4, no. 2, pp. 151-159, 2013.

[17] The Cornerstone Tech Prep, Teaching Mathematics Contextually. Texas: CORD, 1999.

[18] UNESCO, Developing culturally contextualised mathematics resource materials: capturing local practices of Tamang and Gopali communities; a report; 2008. Kathmandu: Lusha Press, 2008.

[19] K. Kadir and L. Masi, "Penggunaan konteks dalam pembelajaran matematika untuk meningkatkan keterampilan sosial siswa SMP," Proceeding KNPM V Malang, pp. 786-796, 2013.

[20] Sadiman, Media Pendidikan. Depok: Rajawali Press, 2012.

[21] D. Y. Park, M. H. Park, and A. B. Bates, "Exploring Young Children's Understanding About the Concept of Volume Through Engineering Design in a STEM Activity: A Case Study," Int. J. Sci. Math. Educ., vol. 16, no. 2, pp. 275-294, 2018.

[22] J. C. Andamon and D. A. Tan, "Conceptual understanding, attitude and performance in mathematics of grade 7 students," Int. J. Sci. Technol. Res., vol. 7, no. 6, pp. 96105, 2018. 